\title{
ŽELEZNÁ JEHLICE Z HRADIŠTĚ KNĚŽÍ HORA U KATOVIC (OKRES STRAKONICE) A OBTÍŽNĚ DATOVATELNÉ NÁLEZY JEHLIC Z VÝŠINNÝCH SÍDLIŠŤ V ŠIRŠÍCH SOUVISLOSTECH
}

\author{
JOSEF HLOŽEK - NAĎA PROFANTOVÁ - PETR MENŠÍK
}

\begin{abstract}
Abstrakt: Raně středověké jehlice vyrobené z různých materiálů patři v širším evropském kontextu k méně běžným nálezům. Nově nalezené exempláře zejména z Kněži hory u Katovic a Tismic dokládaji míru rozšǐreni tohoto artefaktu, možnou jinakost v odiváni v prostředi raně středověkých výšinných poloh a přispivají $k$ diskusi týkající se datace a interpretace solitérních artefaktů nalezených mimo uzavřené celky.
\end{abstract}

Klíčová slova: raný středověk - jehlice - hradiště - Kněži hora u Katovic - Tismice - jižni Čechy - střední Čechy.

An iron pin from the Kněží hora hillfort, near Katovice (Strakonice district) and the finds of pins which are difficult to date from elevated sites in a broader context

\begin{abstract}
Early medieval pins made of different materials belong with less common finds in a broader European context. Newly discovered specimens, especially from Kněži hora, near Katovice and Tismice, bear witness of the spreading of these artefacts and possible differences in clothing at early medieval elevated sites, and contribute to the discussion regarding the dating and interpretation of solitary artefacts excavated outside settlements.
\end{abstract}

Key words: early Middle Ages - pin - hillfort - Kněži hora near Katovice - Tismice - south Bohemia central Bohemia.

\section{Úvod}

Hradiště na vrchu Kněží hora u Katovic na Strakonicku je možné považovat za plošně nejrozsáhlejší opevněnou vícedílnou raně středověkou lokalitu v jižních Čechách. Opevněný areál sestával z akropole a minimálně dvou předhradí zajištěných složitým systémem fortifikace formovaným pravděpodobně delším stavebním vývojem (obr. 1). Na lokalitě známé již od pozdního středověku proběhly drobné archeologické a prospekční práce již v 19. a v první polovině 20. století. Klíčové informace o struktuře katovického hradiště a zastoupených pravěkých a raně středověkých komponentách však přinesl až stratifikovaný archeologický materiál získaný při záchranném archeologickém výzkumu realizovaném v letech 2016-2017. Tento výzkum byl doplněn rozsáhlým nedestruktivním průzkumem lokality a jejího bezprostředního okolí. Součástí tohoto průzkumu byla prospekce za použití detektorů kovů, ${ }^{1}$ která poskytla prozatím největší kolekci kovových artefaktů z této lokality. S ohledem na nedávná narušení plochy hradiště měl detektorový průzkum charakter záchranného výzkumu (podrobně Menšík-Král 2017, 31; Menšík-Starková-Král 2019, 10-14; Čapek-Menšík 2019; Menšík a kol. v tisku).

V článku se budeme věnovat zejména nálezu jehlice $\mathrm{z}$ této lokality a jehlicím z barevných kovů nalezeným systematickou prospekcí s užitím detektorů kovů na středočeském hradišti v Tismicích (okr. Kolín), které patřilo na přelomu 8. a 9. a v první polovině 9. století k nejvýznamnějším v Čechách (Profantová v tisku). V obou př́ípadech jsou určité problémy v datování jehlic zejména proto, že z období před polovinou 9. století prakticky neznáme hroby. Srovnání hrobových a sídlištních nálezů je tak mimořádně obtížné a lze jej využít jen velmi omezeně. Jiným problémem, s nímž se při studiu jehlic setkáváme, je nejednotná terminologie. Některé exempláře jsou v literatuře zaměňovány za jehly (Kudrnáč 1970, 125-126), či jsou interpretovány jako součást záponky, zejména když si archeolog není funkcí předmětu jistý.

1 Za organizaci detektorového průzkumu děkujeme V. Královi. 


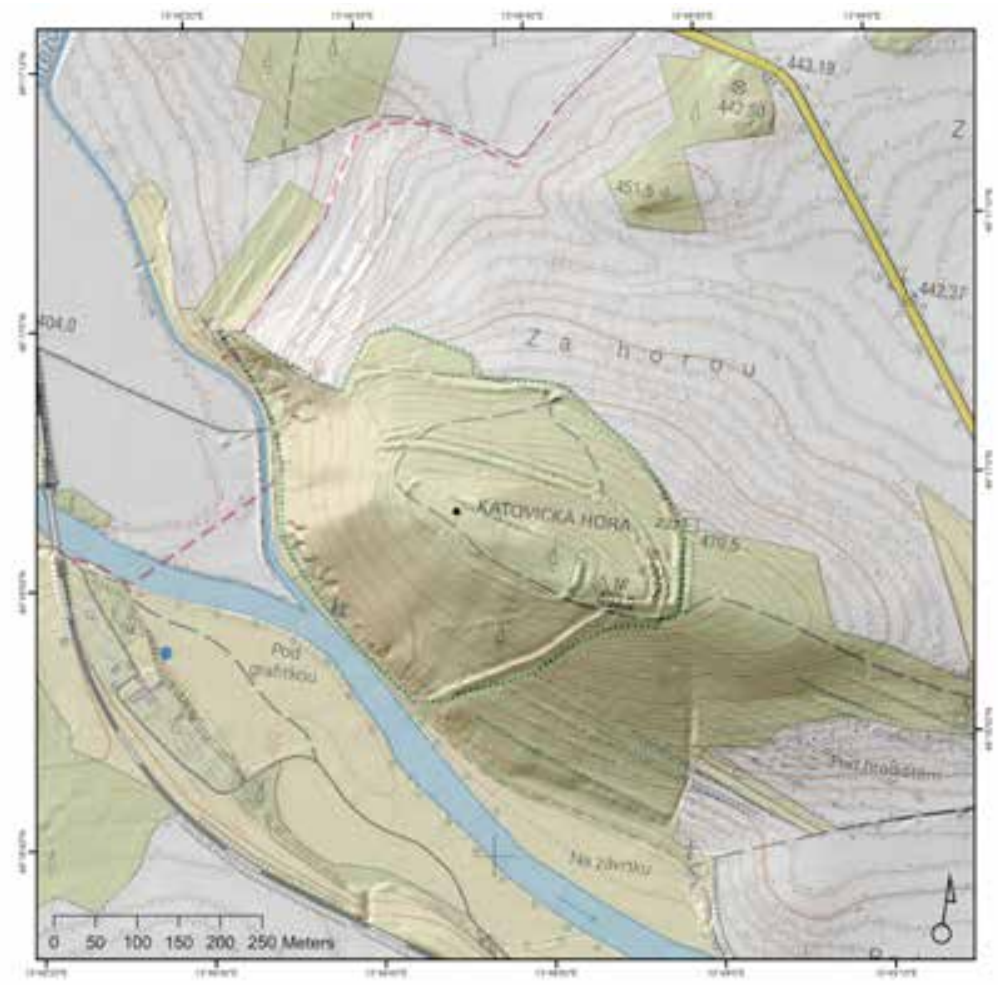

Obr. 1. Hradiště Kněží hora u Katovic (na Základní mapě 1 : 10000 označena jako Katovická hora). Digitální model reliéfu s mapovým podkladem v měřítku $1: 10000$. Podle Menšík-Starková-Král 2019, 22, obr. 2. Místo nálezu označeno kroužkem. Úprava J. Hložek.

Abb. 1. Burgwall Kněží hora bei Katovice (auf einer Grundkarte $1: 10000$ bezeichnet als Berg von Katovice). Digitales Reliefmodell auf Kartenbasis im Maßstab 1 : 10 000. Nach MenšíkStarková-Král 2019, 22, Abb. 2. Die Fundstelle ist mit einem Kreis gekennzeichnet. Bearbeitet von J. Hložek.

\section{Železná jehlice v kontextu železných nálezů z Kněží hory u Katovic}

V rámci detektorového průzkumu lokality byla získána rozsáhlá kolekce kovových artefaktů čítající 100 předmětů. Celkem 97 předmětů bylo vyrobeno ze železa. Pouze tři nalezené artefakty, resp. jejich fragmenty, byly vyrobeny ze slitiny mědi. Nejvíce zastoupenou skupinou předmětů jsou hřeby a jejich části. S ohledem na charakter souboru lze kolekci hřebů datovat rámcově do širokého časového intervalu od raného středověku do 20. století. Druhou skupinou artefaktů z hlediska zastoupení byly blíže neurčitelné předměty ( 29 kusů), resp. blíže neurčitelné fragmenty. Nářadí a nástroje jsou zastoupeny kolekcí nožů, která je tvořena jedenácti exempláři. Minimálně tř́i z nich, s rovným ostřím, rovným, směrem ke špičce mírně zkoseným hřbetem a protáhlým oboustranně odsazeným řapem, je možné datovat do raně středověkého období. Ostatní fragmenty čepelí je s ohledem na míru dochování možné datovat velmi obecně do raného středověku až novověku. Zemědělské nářadí je v souboru získaném z prostoru katovického hradiště zastoupeno zlomkem čepele kosy (obr. 2:1) a částí obloukovitě zahnuté čepele srpu (obr. 2:2). Militaria (obr. 2:3,4) jsou zastoupena dvěma hroty šípů do luku s křidélky a kónickou tulejkou. Datace kovových nálezů (jejich výběr viz obr. 2) i přes delší období využívání některých artefaktů, zejména hrotů šípů do luku s křidélky či artefaktů s omezenou chronologickou 


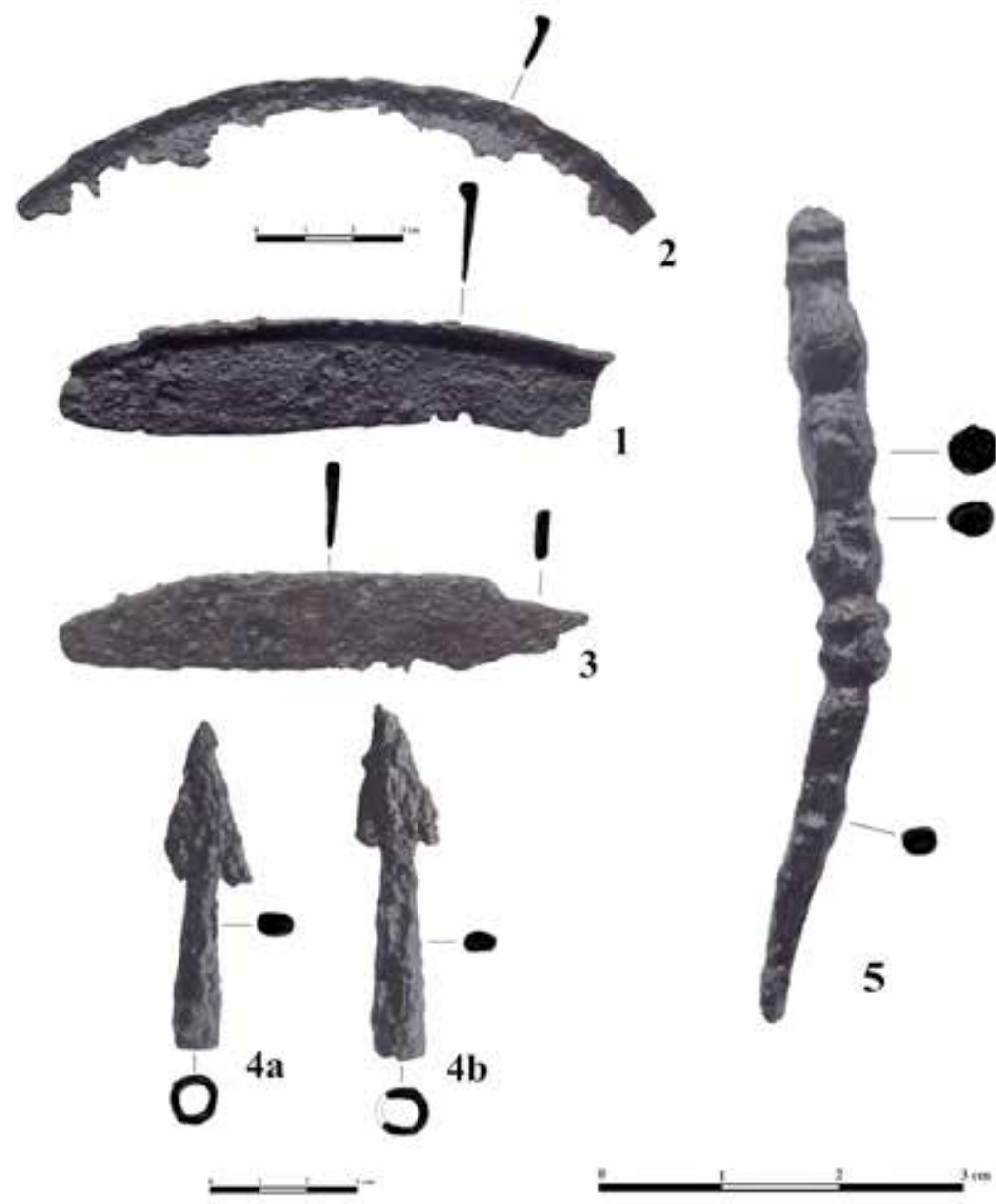

Obr. 2. Hradiště Kněží hora u Katovic. Výběr kovových artefaktů z prospekce v roce 2018. 1 - zlomek čepele kosy, 2 - oblouk čepele srpu, 3 - čepel nože, 4: a, b - hroty střel do luku, 5 - železná jehlice. Foto a kresba J. Hložek.

Abb. 2. Burgwall Kněží hora bei Katovice. Auswahl an Metallartefakten von der 2018 durchgeführten Prospektion. 1 - Fragment eines Sensenblatts, 2 - Bogen eines Sichelblatts, 3 - Messerklinge, 4: a, b - Bogenpfeilspitzen, 5 - Eisennadel. Foto und Zeichnung J. Hložek.

citlivostí, mezi které patř́i především čepele nožů nebo fragmenty srpů, není v rozporu s datací souboru keramiky z této lokality do 9. až první poloviny 10. století (Menšík-Král 2017, 31; Čapek-Menšík 2019; Menšík a kol. v tisku).

Mezi výjimečné nálezy pocházející z katovického hradiště patří fragment železné jehlice s profilovaným krčkem s odlomenou hlavicí a částečně odlomenou jehlou (obr. 2:5 a 3), který zároveň představuje patrně první nález raně středověké jehlice z jihočeského prostředí. Krček jehlice je nepravidelně prŕíčně členěn sedmi vývalky o délce 3-7 mm (obr. 2:5 a 3). Fragment jehlice byl nalezen v jihozápadní části lokality, 5 metrů od vnitřní části valu akropole. Jehlice se nacházela v kulturní vrstvě $20 \mathrm{~cm}$ pod současnou úrovní terénu.

V českém prostředí patří raně stř̌edověké jehlice, podobně jako v širším evropském kontextu, k méně běžným nálezům (k této problematice např́íklad Niederle 1913, 552-553; Rempel 1966, 72-73, 104-105, 113, 118, 136; Krumphanzlová 1967; Kiss 1977, Pl. VIII:3, XIII:14/2, 
13:15/2, 18/2, XX:168/1, XXXII:128/2, L:138/1, LI:150/1, 153/2, LII:187/2; Buchvaldek-SlámaZeman 1978, 84-85; Geisler 1998, Taf. 108, 116, 122, 228, 233, 234, 259, 266, 353; Spiong 2000, 234-237, 272-273; Haberstroh 2004, Taf. 3, 7, 21; Lutovský 2001; 112-113; 2011, 64; Losert 2012, 150, 153, Abb. 13, 17). Dosavadní nálezy jehlic nejen z pohřebišt', ale také ze sídlištních kontextů dokládají jejich výskyt na značném území raně středověké Evropy. Výskyt jehlic je výraznější v oblastech někdejších římských provincií, například na území Panonie, horního Podunají a na území dnešního Slovinska (k jehlicím v době římské Beckmann 1966). V raném středověku můžeme nalézt typovou souvislost a někdy také chronologickou návaznost na pozdně římské exempláře jak v oblasti merovejské a časně karolínské (srov. Pöllath 2002, 130-141), tak i v někdejší Panonii. Jedná se např́iklad o typy s roztepanou, resp. veslovitou hlavicí (namátkou Kiss 1977, tab. XIII:18/2, L:138/1). Na území Čech působí jehlice výrazně cizoroději a setkáváme se s nimi vzácně od přelomu 7. a 8 . století až do počátku vrcholného středověku (například Šolle 1966, 88, 153, 266; Richter 1982, 163; Krumphanzlová a kol. 2013, 141-142, tab. 83:21; Profantová 2015, 84-85, obr. 7:19, 20; Profantová a kol. 2015, 170). U některých nálezů se pak může jednat také o intruzi (např́íklad Bubeník 1992, 218;² Kuna-Profantová a kol. 2005, 190, obr. 233:14, obr. 326:5). Symptomatickým jevem provázejícím jednotlivé nálezy je značná typologická rozmanitost, umožňující jen rámcové typologické třídění těchto artefaktů (srov. např́íklad Krumphanzlová 1967, 583, obr. 1:9). Lépe datovatelné jsou pochopitelně nálezy z kostrových hrobů z poslední třetiny 9. až počátku 11. století. Oproti situaci v Čechách jsou v dnešním východním Bavorsku s větším počtem kostrových hrobů i z 8 . století doloženy jasně se opakující typy jehlic - naprríklad se srdcovitě utvářenou spirálkovou hlavicí, s hlavicí v podobě roztepaného očka apod. (Pöllath 2002, 130-141, např. Taf. 17:7-10, 36:6, 8, 11, 29:4, 16).

$\mathrm{S}$ ohledem na charakter a tvarovou rozmanitost těchto artefaktů je možné předpokládat, že zlomky řady exemplářů, především pak fragmenty nezdobených těl jehlic interpretované zejména jako „zlomky tyčinek“, zůstávají v některých souborech nerozpoznány. Mezi blíže neurčitelnými kovovými předměty z katovického hradiště se obdobné zlomky železných tyčinek kruhového a čtverhranného průřezu vyskytují ve větším počtu. Některé z těchto tyčinek patrně představují části těl hřebů, může se jednat i o zlomek šídla. Vyloučit však nelze ani možnost, že by mohlo minimálně v některých případech jít o fragmenty železných jehel či jehlic. S obdobnou situací se setkáváme např́iklad u nálezů železných tyčinek z raně středověkých hrobů v poloze Na Týnici v blízkosti budečského hradiště (Štefan-Krutina 2009, 179, obr. 43 - H 40/1, H79/1, H73/1, k dalším lokalitám s obdobnými nálezy například Jelínková 2005, 550, obr. 1). Zlomky tyčinek z barevných kovů pak mohou být zaměnitelné především s jehlami spon, jejichž použití v raném středověku je možné považovat spíše za raritní. Zaznamenán však byl jejich výskyt např́íklad v Tismicích, kde byla prospekcí nalezena torza spon z doby rrímské (nepublikováno).

\section{Kovové jehlice z prostředí raně středověkých Čech}

Neúplné jehlici z hradiště u Katovic se profilací krčku blíží bronzová jehlice (?) z velkomoravského prostředí ze Starého Města u Uherského Hradiště z polohy na Na Valách, z hrobu 6/48 (Hrubý 1955, 273, 410 tab. 56:4; Krumphanzlová 1967, 581, obr. 1:5, 9). Součástí nálezového celku z hrobu dospělého muže (6/48) bylo železné nákončí a ostruhy s krátkým bodcem, ploténkami a s průvlečkou. Jehlice (?) se pak nacházela u chodidla pravé nohy (Hrubý 1955, 410). Interpretace artefaktu coby jehlice tak není zcela přesvědčivá. S ohledem na nálezové okolnosti se pravděpodobně nejedná o součást oděvu, ale mohlo by jít spíše o ,starožitnost“ či intruzi. ${ }^{3} \mathrm{~S}$ vývalkovitě profilovaným krčkem se setkáváme také u bronzového exempláře jehlice z hrobu č. 147 v Mušově, datovaného do doby římské (Jelínková 2005, 550 obr. 1:6). Další exempláře s profilovaným tělem, resp. krčkem pocházejí z Chebu a Lochenic na Královéhradecku (Krumphanzlová 1967, 586 obr. 1:8). Jehlice z Lochenic je však kladena až do druhé

2 Ani v tomto prŕípadě to není zcela jednoznačné, obdobné jehlice se ojediněle vyskytují i v období raného středověku.

3 V. Hrubý uvažoval o možnosti laténského stáří. Po konzultaci s M. Chytráčkem z ARÚ AV ČR, Praha, v. v. i., se domníváme, že se spíše nejedná o laténský artefakt. Ovšem bez studia z autopsie to nelze říci s jistotou. 


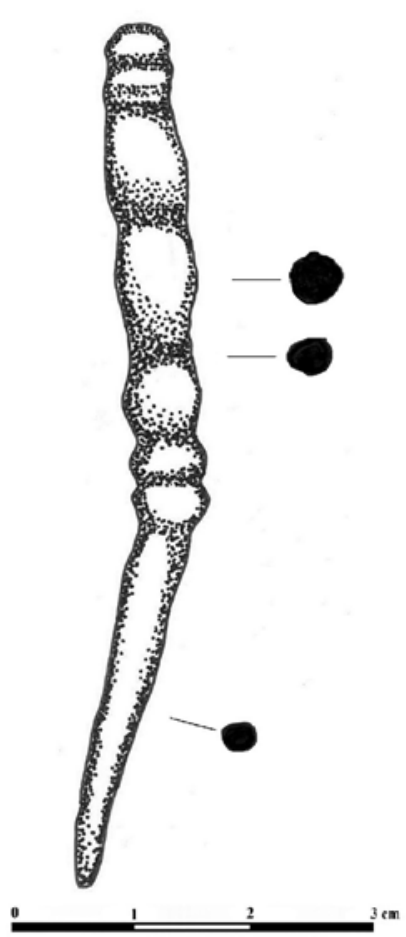

Obr. 3. Hradiště Kněží hora u Katovic. Železná jehlice z prospekce v roce 2018. Kresba J. Hložek.

Abb. 3. Burgwall Kněží hora bei Katovice. Eisennadel von der 2018 durchgeführten Prospektion. Zeichnung J. Hložek. u Podbořan (Bubeník 1997, 66, Abb. 16:12) a železné jehlice z Kozárovic, možné zaznamenat nárůst počtu exemplářů $\mathrm{v}$ souvislosti s opakovanými detektorovými průzkumy lokalit ze sledovaného období. Kromě Kněží hory u Katovic se jedná zejména o Tismice s deseti exempláři jehlic s nejistým datováním (obr. 4 a 5; tab. 1), Kosoř - Praha-Radotín se dvěma železnými jehlicemi a Sv. Jan pod Skalou rovněž se dvěma železnými jehlicemi. Jeden dobře určitelný exemplář jehlice importované z Karpatské kotliny pochází také z českomoravského pomezí (nález D. Vícha). ${ }^{5}$ $\mathrm{Z}$ důvodu sporného datování zůstávají tyto nálezy z polykulturních výšinných lokalit obvykle nepublikované. Většina z doposud nalezených exemplářủ jehlic může být pojímána jako importy z merovejsko-karolinského prostředí, naprríklad Kosoř - Praha-Radotín (Profantová 2015, 85, 91, obr. 7:19-20), či naopak z jihovýchodu (nález D. Vícha). V př́ípadě hradiště Tismice pak může jít i o domácí produkty, nebot' na této lokalitě byla prokázána na základě dalších artefaktů existence kovotepecké a kovolitecké výroby (Profantová 2016a, obr. 1 a 2; 2018, 244-246, zejm. Abb. 10:3-7, 13/16, 18/21).

\section{Problémy datování jehlic z Tismic}

Na prríkladu nálezů jehlic pocházejících z detektorové prospekce hradiště v Tismicích (obr. 5) je možné demonstrovat některé z problémů metodického rázu souvisejících s touto skupinou artefaktů. Nalezené jehlice $\mathrm{z}$ barevných kovů $(10 \mathrm{ks})$ mohou patřit bud' ranému středověku,

4 V merovejském prostředí jsou obvykle jehlice s vývalky zdobeným krčkem a nevýraznou hlavicí vyráběny z bronzu, když ze železa, tak se stř́brnou fólií a jsou datovány do konce 6. a do 7. století (Losert-Pleterski 2003, 49, Abb. 1).

5 Tímto D. Víchovi děkujeme za možnost jehlici zmínit. 
jako většina všech jiných datovatelných nálezů (minimálně 150 do r. 2018 - Profantová v tisku), době římské, jíž patří jen několik neúplných spon a dvě opasková kování, aniž bychom zjistili soudobou keramiku (jedno neúplné kování viz Profantová-Stolz 2006, Fototab. 8:10); zde bychom však mohli uvažovat také o jejich dalším využití coby archaik (k této problematice Ungerman 2009) či jen jako suroviny, nebo je přičlenit i vrcholnému středověku až novověku (obr. 4, tab. 1). ${ }^{6}$ Vzhledem k existenci dvojice shodných jehlic $(4: 1,2)$ a dvou velmi podobných (4:3 a další nevyobrazený exemplář, viz tab. 1:473/015) není možné považovat jejich výskyt za zcela náhodný. Ještě upozorníme, že pouze jehlice č. 145 je kompletní i co se týká délky, byt' je ohnutá (obr. 4:6), u ostatních jejich délku neznáme.

\begin{tabular}{|c|c|c|c|c|c|}
\hline Č. nálezu & Materiál & Délka v mm & Hlavice & Krček & Datování \\
\hline 89 & slitina $\mathrm{Cu}$ & 45 & kulovitá s perlovcem po obvodu & $\begin{array}{l}\text { při styku s hlavicí } \\
\text { členěn jedním } \\
\text { vývalkem }\end{array}$ & RS / pozd. VS / No \\
\hline 145 & slitina $\mathrm{Cu} / \mathrm{Zn}$ & 82 & kruhová s otvorem & $\begin{array}{l}\text { při styku s hlavicí } \\
\text { členěn jedním } \\
\text { vývalkem }\end{array}$ & $\begin{array}{l}\text { RS / doba } \\
\text { halštatská }\end{array}$ \\
\hline $97 / 014$ & slitina $\mathrm{Cu}$ & 45 & kulovitá s perlovcem po obvodu & $\begin{array}{l}\text { při styku s hlavicí } \\
\text { členěn jedním } \\
\text { vývalkem }\end{array}$ & - \\
\hline $218 / 015$ & slitina $\mathrm{Cu}$ & - & $\begin{array}{l}\text { roztepaná (nevýrazné } \\
\text { roztepání) }\end{array}$ & - & RS: doba avarská \\
\hline $436 / 015$ & slitina $\mathrm{Cu}$ & 39 & $\begin{array}{l}\text { s hráněnou bikónickou / dvou- } \\
\text { pyramidovou hlavicí }\end{array}$ & $\begin{array}{l}\text { dva vývalky na } \\
\text { krčku při styku } \\
\text { s hlavicí }\end{array}$ & RS / doba římská \\
\hline $471 / 015$ & slitina $\mathrm{Cu}$ & 7 & $\begin{array}{l}\text { hlavice zdobená vířivým } \\
\text { motivem }\end{array}$ & - & RS / doba římská \\
\hline $473 / 015$ & slitina $\mathrm{Cu}$ & 43 & s rozšířenou hlavicí & - & $?$ \\
\hline $733 / 017$ & slitina $\mathrm{Cu}$ & 40 & $\begin{array}{l}\text { s hráněnou skoro pravoúhlou } \\
\text { protáhlou hlavicí ukončenou } \\
\text { plasticky oddělenou „,čepičkou“ }\end{array}$ & - & RS / No \\
\hline $746 / 017$ & slitina $\mathrm{Cu}$ & 29 & $\begin{array}{l}\text { s hlavicí tvořenou čtyřmi plas- } \\
\text { tickými lístky }\end{array}$ & - & $\mathrm{RS}(?)$ \\
\hline $884 / 018$ & slitina $\mathrm{Cu}$ & 18 & s odlomenou hlavou & - & $\begin{array}{l}\text { RS, nad obj. } 10 \\
\text { S 4/18 }\end{array}$ \\
\hline
\end{tabular}

Tab. 1. Přehled nálezů jehlic z Tismic. Úprava N. Profantová.

Tab. 1. Übersicht der Nadelfunde aus Tismice. Bearbeitet von N. Profantová.

V rámci rozboru nalezené kolekce jehlic se zaměříme na tři typy: jehlice s kulovitou hlavicí zdobenou po maximálním obvodu perlovcem a malým krčkem (č. 89, 97/014, obr. 4:1, 2), jehlice s otvorem v kruhové hlavici (č. 145, obr. 4:6) a jehlice s hráněnou bikónickou, resp. dvoupyramidkovou hlavicí a vývalkovitě členěným krčkem (č. 436/015, obr. 4:3). Raně středověké stáŕí těchto exemplářů je s ohledem na další analogie velmi pravděpodobné. Nejbližší analogií k jehlici s kulovitou hlavicí a perlovcem je exemplář bronzové pozlacené jehlice z Břeclavi-Pohanska, z dětského hrobu č. 131 z pohřebiště u prvního kostela v poloze Velmožský dvorec (Kalousek 1971, obr. 131, tab. 34:13) - jehlice se nacházela za lebkou, mohla tedy souviset, mimo jiné, s účesem. Hlavici jehlice popisuje J. Kalousek jako „dutý elipsoid ovinutý po obvodu granulovaným drátkem“. V obdobném kulturním prostředí se pak v jednom z velmi bohatých hrobů (120/89) v Zalaváru-Hadrianskirche vyskytla jehlice spolu s gombíky a s párem desetibubínkových náušnic a s rozetovitou sponou zdobenou filigránem (Szőke 2010, 40, Abb. 18:5). Tento celek je datován do 60.-80. let 9. století, přičemž šperky měly být vyrobeny ve středu 9 . století. Tato

$6 \mathrm{Z}$ pravěkého osídlení byl bezpečně doložen jen eneolit. 


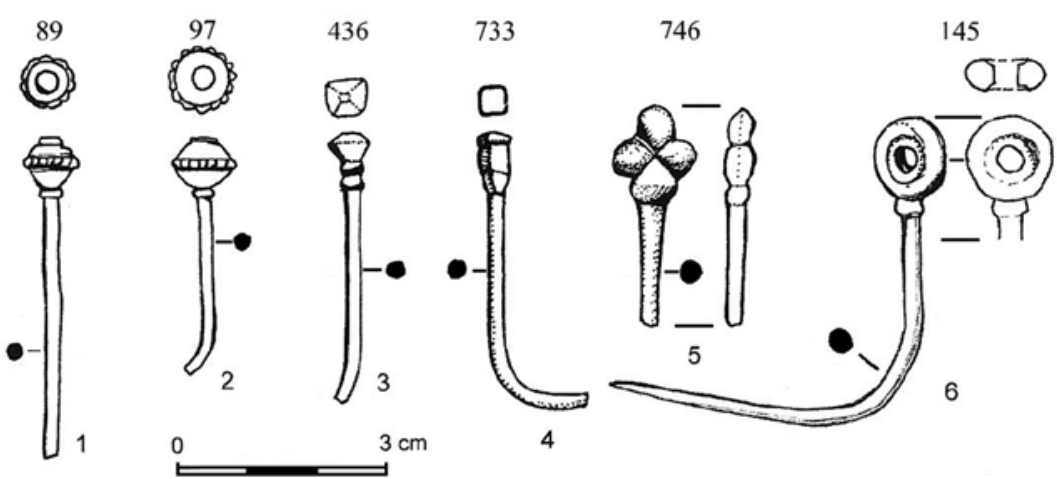

Obr. 4. Tismice, okr. Kolín. Kolekce jehlic z hradiště ze slitiny mědi z prospekce z let 2013-2019. Kresba L. Raslová; úprava J. Hložek.

Abb. 4. Tismice, Bezirk Kolín. Kollektion Eisennadeln vom Burgwall aus einer Kupferlegierung von der 2013-2019 durchgeführten Prospektion. Zeichnung L. Raslová, bearbeitet von J. Hložek.

jehlice je na rozdíl od našich pozlacená, má shodné členění s pomocí granulace, resp. filigránu, ${ }^{7}$ i když v našem případě jsou „kuličky“ hrubší a působí až jako výčnělky po vsecích. Starší verzí je bronzová dutá jehlice z hrobu č. 47 z Weismain-West (Schwarz 1984, Abb. 46:5). V tomto př́ípadě se nacházela u levé klíční kosti blíž ke krčním obratlům (Pöllath 2002, Taf. 161), funkce tedy spíše souvisela s oděvem. Tento hrobový celek patří podle K. Schwarze díky velkým zapínacím záušnicím konci 7.-8. století, ovšem nelze vyloučit ani datování do počátku 9. století (srov. výhrady k dataci některých hrobů Pöllath 2002). Pohřebiště jako celek vykazuje určité shodné rysy s pohřebišti v Rakousku i na Moravě (v nejmladši fázi). R. Pöllath upozorňuje ještě na jehlici z hrobu 144 na pohřebišti Kelheim-Staubing (Pöllath 2002, 141) v Dolním Bavorsku, chronologii však nezpřeš̌uje.

Problém je, že jehlice z Tismic nebyly duté, ale patrně lité, jsou hrubší verzí - dostupnou variantou - výše uvedených. S jistou opatrností je tedy klademe do první a druhé třetiny 9 . století. Nová radiokarbonová data ze sondy 4/2018 z Tismic ukazují maximálně do let 880-882. Vzhledem k plató v rámci 9. století předpokládá N. Profantová konec raně středověkého osídlení hradiště spíše o něco dříve (60. léta 9. století?). Bude však tř̌eba vyčkat na početnější sérii přírodovědných dat, něž dospějeme $\mathrm{k}$ jednoznačnějším závěrům.

Další jehlice (č. 145, obr. 4:6, obr. 5) s kruhovou hlavicí se středovým otvorem nalezená v prostoru předhradí Tismic by s jistou dávkou opatrnosti mohla po typologické stránce patřit do doby halštatské. ${ }^{8}$ Rovněž by se ale mohlo jednat o pozdně (?) merovejský import. Exemplář s kruhovou hlavicí s otvorem bez dalších artefaktů ze stejného kontextu, avšak méně masivní známe z pohřebiště Neuburg an der Donau, z hrobu 138 (Höke 2013, Taf. 45). Kruhovou hlavici se středovým otvorem a vývalek na krčku má také jehlice z Bliederstedtu s masivní jehlou, resp. tělem, patrně z 8. století (Rempel 1966, Taf. 44A:4; Krumphanzlová 1967, 586, obr. 1:18). Podle výsledků rentgenfluorescenční analýzy provedené ve Ústavu jaderné fyziky v Řeži u Prahy v roce 2014 je jehlice $\mathrm{z}$ Tismic č. 145 vyrobena ze slitiny barevných kovů s příměsí zinku. Na základě složení použité slitiny uvažujeme spíše o raně středověkém stáří této jehlice.

Na obdobné problémy spojené s nejednoznačnou datací můžeme poukázat $\mathrm{v}$ př́ípadě jehlice s drobnou hráněnou bikónickou, resp. dvoupyramidkovou hlavicí a dvěma vývalky na krčku (obr. 4:3). Tato jehlice může patřit době římské, stejně jako ranému středověku. Hráněná bikónická, resp. dvoupyramidková, trochu větší hlavice jehlice byla nalezena v hrobě č. 477 v Zamárdi-Rétiföldek (Bárdos-Garam 2009, Taf. 59:4) na pohřebišti z doby avarské (7.-8. století), byt'

7 Bez studia z autopsie nebo dobré fotografie nelze říct, zda jde o granulaci, či filigrán.

8 Osídlení z doby halštatské však na hradišti nebylo zjištěno. 


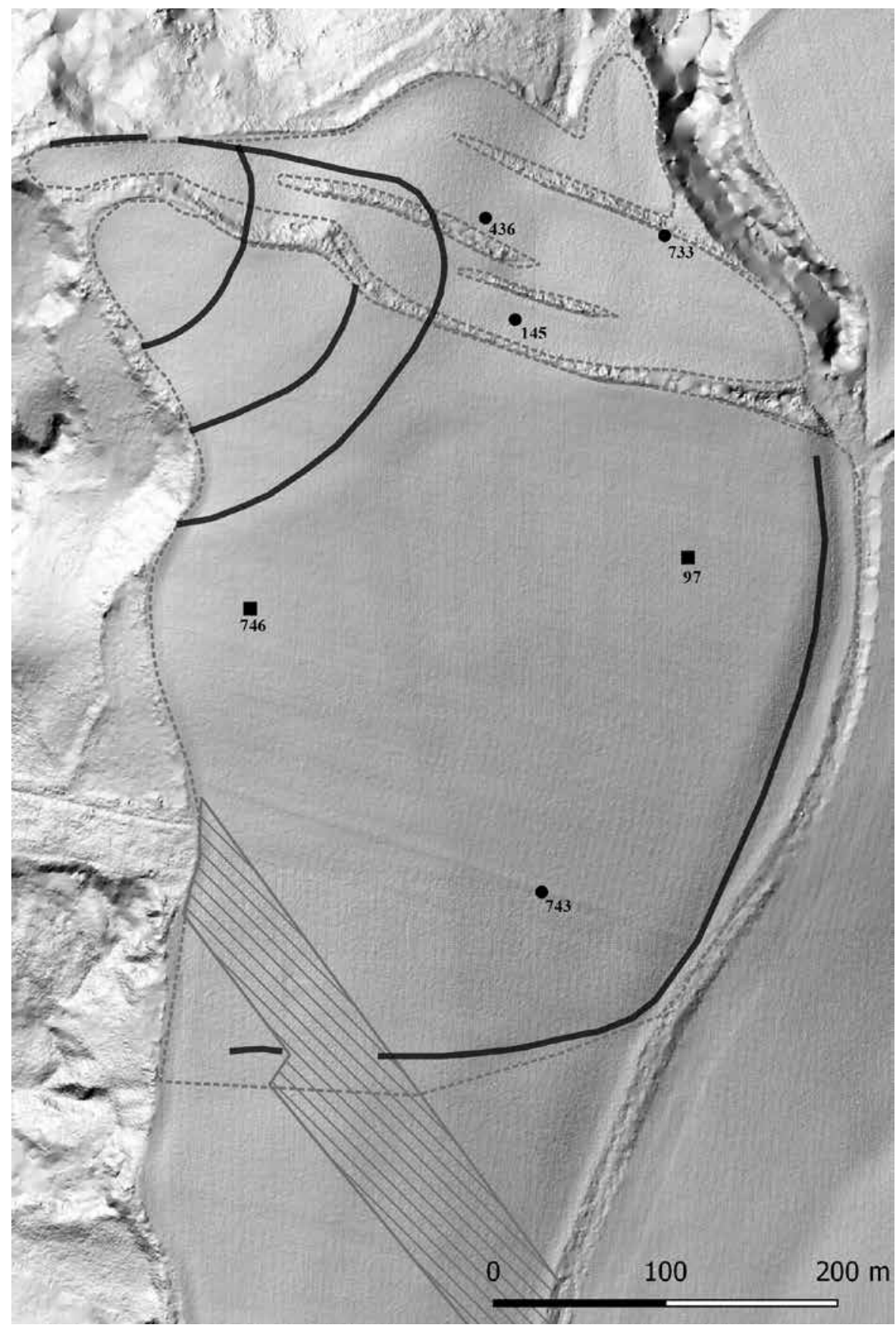

Obr. 5. Tismice, okr. Kolín. Rozmístění zaměřených nálezủ jehlic na nově definovaném členění hradiště s využitím kompletně provedené magnetometrie R. Křivánka. Čtverečky - zaměřené jehlice s vazbou na karolinské a sociálně vyšší prostř̌edí (s kulovitou po obvodu zdobenou hlavicí). Grafika K. Levá.

Abb. 5. Tismice, Bezirk Kolín. Verteilung der vermessenen Nadelfunde auf der neu definierten Gliederung des Burgwalls unter Heranziehung der von R. Křivánek komplett durchgeführten Magnetometrie. Quadrate - vermessene Nadeln mit Bezug zum karolingischen und sozial höhergestellten Milieu (mit kugelförmigen am Umfang verzierten Kopf). Grafik K. Levá. 
tento exemplář nemá vývalkovitě členěný krček. Analogií je i jehlice z Mikulčic č. 594-399/67 pod obj. 656A (Klanica 1968, Taf. 54:9). V tomto př́ípadě je i výše zmíněná jehlice z Rubína u Podbořan jistou analogií s možným datováním do pokročilého 8.-9. století. ${ }^{9}$ Proto může jehlice z Tismic pocházet z konce 8. a počátku 9. století. Vzdálenější analogií k jehlici č. 733 je jehlice z Yorku (Mainman-Rogers 2000, Fig. 1274:10453), ovšem tady je třeba velké opatrnosti, obě mohou vycházet z nějaké pozdně rrímské či merovejské předlohy.

K poslední jehlici s hlavicí tvořenou čtyřmi plastickými lístky (č. 746/017, obr. 4:5, obr. 5) neznáme př́mou analogii. Ovšem v karolinském prostředí se objevují ostruhy s krátkým bodcem se stejně členěnou a zdobenou ploténkou a nýtem umístěným na spodní straně, například nález z hrobu B v Bendorfu (Gabriel 1981, Abb. 4). Zmíněný hrob je datován do první poloviny 9. století a je velmi pravděpodobné, že tvar a výzdoba hlavice jehlice mohly být inspirované $\mathrm{v}$ karolinském prostřed $1^{10}$ a ozdoba mohla vzniknout v době od konce 8 . do poloviny 9 . století. ${ }^{11}$ Tento předběžný závěr koresponduje s archeologickým obrazem dálkových kontaktů lokality v Tismicích, kde se vedle výrobků byzantsko-pozdně avarského typu vyskytly př́ímé karolinské importy (nákončí, průvlečka), včetně mince Karla Velikého ražené před rokem 793 v Amiens (Militký-Profantová-Videman 2013; Profantová-Stolz 2006, 826, obr. 5:7, 8; Profantová 2016, 23, obr. 10:2), a lze tudíž potvrdit nezávisle alespoň kontakt s karolinským prostředím ve sledované době. Pokud tedy alespoň čtyři či pět jehlic je raně středověkých, rozhojňují velmi malou skupinu ženských ozdob z Tismic. Mezi ně dále řadíme olověný př́ivěsek s vypnulinami na aversu, lunicovitou náušnici s hvězdicovitým přívěskem, zlomek nepublikovaného bronzového náramku (č. 713/017) a velmi nejistě pak lunicovitý př́ivěsek původně s nějakou vložkou (Profantová-Stolz 2006, 813, 816, obr. 3:4, 9, fototab. 3:3).

Vzhledem k spíše nejisté dataci jehlic můžeme konstatovat, že jehlice s kulovitou hlavicí $\mathrm{v}$ hrobech zdobily jak účes, tak nejspiše i oděv, objevily se v hrobech nedospělých i dospělých žen. V př́ípadě ostatních jehlic z Tismic nemá smysl je porovnávat s mladšími hroby s jehlicemi v Čechách, nebot' představují odlišné typy a jejich polohu lze zjistit jen v několika případech.

Jehlice zdobily ženy na dnešním území Čech relativně vzácně, s jistou pravidelností, zdobily jak šat, tak nejspíše i účesy či mohly upínat i čepce či jinou formu zahalení vdaných žen (naprŕklad Vida 1997/1998, 566-568, 813, obr. 3; k této problematice dále Jelínková 2005). V rámci západní i jihovýchodní Evropy lze v kvalitně dokumentovaných případech rozlišit podle polohy v hrobu jehlice použité jako spínadlo oděvu od jehlic použitých v účesu či čepci (nalezené na či pod lebkou), př́ípadně na závoji, počty nálezů na lebce a na hrudi na pohřebištích avarského kaganátu jsou víceméně vyrovnané, i tady se však pracuje spíše s variantami jejich užití (např́íklad Vida 1997/1998, 565-568, 813, obr. 3). Počty hrobů s jehlicemi jsou pak regionálně odlišné $\mathrm{v}$ rámci ř́iše a ubývá jich $\mathrm{v} 8$. století, u některých jehlic je pravděpodobná spojitost s obdobnými typy merovejského okruhu. V merovejské oblasti se objevují i dvojice jehlic, kdy jedna se nalezla u ramene a druhá na lebce jako součást zavinutí závoje (?) (Geisler 1998, Taf. 234: 5, 6), ale i dvě jehlice po obou stranách hlavy, resp. lebky (Vida 1997/1998, 566). V př́ípadě výskytu na rameni je preferováno pravé a jedná se o dlouhou jehlici. Zároveň se v hrobech doby merovejské vyskytují železné, vzácněji i stř́brné jehlice s drobnými hlavicemi v prostoru opasku či blíže kosti stehenní nad koleny, které spínaly váček u opasku nebo pohřební roucho či rubáš (Losert-Pleterski 2003, 245, Abb. 53:6-12), většinou patří ještě 6. či přelomu 6. a 7. století.

Obecně se však jehlice spínající oděv či závoj vyskytují na levé i pravé straně hrudi. Interpretace jejich funkce coby spínadel různých částí oděvu zůstává, především s ohledem na průběh dekompozice skeletu zejména v primárním dutém prostoru a s ní spojené možné posuny drobných artefaktů, nejednoznačná. Př́íkladem může být dlouho trvající pohřebiště v Čakajovcích, kde byla v prŕípadě hrobu 646 (Rejholcová 1995, tab. 104:8) zaznamenána přítomnost jehlice se stočenou hlavicí na levé straně hrudi. V prřípadě hrobu 661 s esovitou záušnicí (Rejholcová 1995,

9 Problém jejího datování může pomoci řešit RFA analýza - pokud by složení bylo typické pro konkrétní období (např. přítomnost Zn). 10 Základní výzdobné motivy se běžně uplatňovaly na více typech artefaktů a za použití různých materiálů, např. kov/parohovina.

11 I vzhledem k absenci výraznějšího pravěkého osídlení. Typově vzdálenější je jehlice s náznakem plastických lístků na kulovité hlavici ze Starého Města, osady I, př́ikopu II a vrstvy V datované do 3. čtvrtiny 9. století (Hrubý 1965, 276, obr. 84:2 a tab. na s. 285). 
tab. 106:8) se obě jehlice se stočenou hlavicí nacházely na hrudi. Jednoduché železné jehlice se vyskytovaly v etapách pohřbívání A-C / 9.-10. století (Hanuliak-Rejholcová 1999, 77, obr. 73).

Jistým vodítkem by pak mohla být velikost jehlice, nebot' v dostupných souborech je možné rozlišit drobné a masivní kusy, které nejspíše spínaly svrchní část oděvu. Teprve výskyt jehlic v lépe datovatelných situacích tak může pomoci podchytit typy, které jsou časově omezené i v rámci raného středověku. Je pravděpodobné, že v západních a jihozápadních Čechách se mohly objevovat častěji vzhledem $\mathrm{k}$ př́hraničním stykům s oblastí prosycenou karolinskými vlivy západně od Čech. I v Čechách však již lze rozlišit jehlice luxusní (Stará Kouřim), jehlice průměrné kvality (bronzové jehlice s kulovitou hlavicí a výzdobou po obvodu z Tismic) a jehlice spíše podprůměrné kvality (jednoduché železné jehlice s očkem či nezdobené kusy). Mohou nepočetné nálezy jehlic naznačovat př́tomnost žen $\mathrm{v}$ jiném typu oděvu? To zatím $\mathrm{s}$ jistotou nevíme. Každopádně je patrný zkreslený archeologický obraz z doby před nástupem kostrových hrobů - kdy mezi nálezy z hradišt' téměř chybí ozdoby spojované s krojem žen, a naopak v nejmladších hrobech druhé poloviny 10. století zase chybí nálezy spojované s mužským krojem.

\section{Závěr a diskuse}

Nové nálezy kovových artefaktů významnou měrou rozšiřují naše poznání hmotné kultury raného středověku nejen v jižních Čechách. Mezi výjimečné nálezy pocházející z katovického hradiště patří fragment železné jehlice, který zároveň pravděpodobně představuje první nález raně středověké jehlice z jihočeského prostředí. Nalezená jehlice s vývalkovitě členěným krčkem vykazuje jistou míru podobnosti nejen s exempláři pocházejícími z velkomoravského a merovejsko-karolinského prostředí, ale také s exempláŕi datovanými do stupně B2 doby římské, a to zejména s ohledem na vývalkovitě členěný krček nalezené jehlice. Zde se ale přikláníme spíše k raně středověkému stáŕí této jehlice. Nevylučujeme však možnost tvarové inspirace jehlicemi z doby římské. Nálezy jehlic $(10 \mathrm{ks}) \mathrm{z}$ barevných kovů jsou nejpočetnější ze sídlištního, orbou narušeného kontextu rozsáhlého hradiště Tismice ve středních Čechách (8.-9. století). Ovšem jejich datování není obvykle jednoznačné zejména s ohledem na ojedinělé kovové artefakty z doby ř́mské nově zjištěné prospekcí na této lokalitě. Typ s kulovitou hlavicí zdobenou po obvodu se vyskytl ve shodné podobě na lokalitě dvakrát a má analogie na pohřebišti při kostele č. I v Břeclavi-Pohansku, v Zálaváru-Hadrianskirche zhruba z poloviny 9. století, stejně jako v o něco starších hrobech na západě. Tismické jehlice jsou spíše lité a výzdoba je hrubší, jedná se pravděpodobně o běžnější a levnější variantu. Některé z dalších jehlic patří nejspíše ranému středověku a představují ojedinělou stopu po ženském kroji v době před nástupem kostrového pohřbívání v Čechách. Nové nálezy jehlic v Čechách pak dokládají nejen komplikovanost využití výpovědního potenciálu souborů získaných za pomoci detektorů kovů, ale také široké spektrum vztahů a vlivů z různých oblastí Evropy, které formovaly raně středověkou hmotnou kulturu. Otázkou pak i nadále zůstává, do jaké míry nálezy z hradišt' pro starší úsek raného středověku (asi do poloviny 9. století) nahrazují dosud adekvátně nepoznané či velmi chudé hrobové celky (z žárových mohyl) v Čechách. Je zřejmé, že tyto průzkumy musejí být doplňovány destruktivními výzkumy s jasnými kontexty, bez této kombinované strategie výzkumu zůstane velká část nálezů z povrchových průzkumů chronologicky nezařazená. Tento článek však nemůže nahradit větší studii sledující systematicky problematiku raně středověkých jehlic ve středoevropském kontextu.

Podíl N. Profantové vznikl v rámci grantu GA ČR č. 18-00477S „Mezi avarskou a karolinskou říší“.

\section{Literatura}

BÁRDOS, É.-GARAM, É., 2009: Das awarenzeitliche Gräberfeld in Zamárdi-Rétiföldek. Teil I. Monumenta Avarorum Archaeologica. Vol. 9. Budapest. 
BECKMANN, B., 1966: Studien über die Metallnadeln der römischen Kaiserzeit im freien Germanien. In: Saalburg Jahrbuch XXIII, 5-100. Berlin.

BUBENÍK, J., 1992: Výzkum vrchu Rubín (Dolánky, obec Podbořany, okr. Louny) a jeho okolí v letech 1984-1989. Předběžná zpráva, AR XLIV, 216-230.

- 1997: Die Besiedlung des südöstlichen Vorfelds des Berges Rubín in der Burgwallzeit und ihre Chronologie (Ausgrabungen in den Jahren 1984-1991), PA LXXXVIII, 56-106.

BUCHVALDEK, M.-SLÁMA, J.-ZEMAN, J., 1978: Slovanské hradiště u Kozárovic, Praehistorica 6, 84-85.

ČAPEK, L.-MENŠÍK, P., 2019: Raně středověká keramika z Hradiště Kněží hora u Katovic (okres Strakonice) - Frühmittelalterliche Keramik vom Burgwall Kněží hora (Pfaffenberg) bei Katovice (Bezirk Strakonice), AH 44, 357-381.

GABRIEL, I., 1981: Karolingische Reitersporen und andere Funde aus dem Gräberfeld von Bendorf, Kr. Rendsburg-Eckernförrde, Offa Bd. 38, 245-258.

GEISLER, H., 1998: Das frühbairische Gräberfeld Straubing-Bajuwarenstraße I. Tafelband. Rahden/Westf.

HABESTROH, C. et al., 2004: Das frühmittelalterliche Gräberfeld von Wirbenz, Gde. Speichersdorf, Lkr. Bayreuth. München.

HANULIAK, M.-REJHOLCOVÁ, M., 1999: Pohrebisko v Čakajovciach (9.-12. storočie). Vyhodnotenie. Bratislava - Nitra.

HÖKE, B., 2013: Der Merowingerzeitliche Bestattungsplatz von Neuburg a. d. Donau, St. Wolfgang. Materialhefte zur bayerischen Archäologie 97. Kallmünz.

HRUBÝ, V., 1955: Staré Město. Velkomoravské pohřebiště „Na valách“-Staré Město. Die grossmährische Begräbnisstätte „Na valách“. Praha.

- 1965: Staré Město - velkomoravský Velehrad - Velehrad - Staré Město - Die Centrum des Grossmährischen Reiches. Praha.

JELÍNKOVÁ, D., 2005: Příspěvek k poznání ženského oděvu ve střední a mladší době hradištní, AR LVII, 549-560.

KALOUSEK, F., 1971: Břeclav - Pohansko I. Velkomoravské pohřebiště u kostela - Großmährisches Gräberfeld bei der Kirche. Brno.

KISS, A., 1977: Avar cemeteries in County Baranya. Cemeteries of the Avar Period (567-829) in Hungary Vol. 2. Budapest.

KLANICA, Z., 1968: Výsledky čtrnácté sezóny výzkumu v Mikulčicích, okr. Hodonín, PV 1967, 61-85.

KRUMPHANZLOVÁ, Z., 1967: Časně středověké nálezy jehlic v českých zemích, PA LVIII, 580-591.

KRUMPHANZLOVÁ, Z. a kol., 2013: Raně středověké pohřebiště v Praze-Lahovicích. Praha.

KUDRNÁČ, J., 1970: Klučov. Staroslovanské hradiště ve středních Čechách. K počátkům nestarších slovanských hradišt' v Čechách. Praha.

KUNA, M.-PROFANTOVÁ, N. a kol., 2005: Počátky raného středověku v Čechách. Archeologický výzkum sídelní aglomerace kultury pražského typu v Roztokách. Praha.

LOSERT, H., 2012: Die Slawen in Nordostbayern, Fines Transire 21, 139-168.

LOSERT, H.-PLETERSKI, A., 2003: Altererding in Oberbayern. Struktur des frühmittelalterlichen Gräberfeldes und „Ethnogenese“ der Bajuwaren. Berlin - Ljubljana.

LUTOVSKÝ, M., 2001: Encyklopedie slovanské archeologie v Čechách, na Moravě a ve Slezsku. Praha.

- 2011: Jižní Čechy v raném středověku. Slovanské osídlení mezi Práchní a Chýnovem. České Budějovice.

MAINMAN, A. J.-ROGERS, N. S. H., 2000: Craft, industry and Everyday Life: Finds from Anglo-Scandinavian York. York.

MENŠÍK, P.-KRÁL, V., 2017: „Kněží hora“ u Katovic. Raně středověká pevnost nad řekou Otavou z pohledu archeologického bádání. Strakonice.

MENŠÍK, P.-STARKOVÁ, L.-KRÁL, V., 2019: Hradiště na Strakonicku. Předchůdci moderních opevněných sídel v pravěku a raném středověku z pohledu archeologie. Strakonice.

MENŠÍK, P. a kol., v tisku: Menšík, P.-Čapek, L-Hložek, J.-Kočár, P.-Sůvová, Z.-Hošek, J., Die Höhensiedlung und der Burgwall Katovice „Kněží hora“. Ein überregionales Zentrum im urzeitlichen und frühmittelalterlichen Südböhmen, Archäologisches Korrespondenzblatt.

MILITKÝ, J.-PROFANTOVÁ, N.-VIDEMAN, J., 2013: Pozdně římské mince a denár Karla Velikého (768-814) z areálu hradiště Tismice, Numismatický sborník 27, 35-46.

NIEDERLE, L., 1913: Život starých Slovanů. Díl 1, svazek 2. Základy kulturních starožitností slovanských. Praha.

PÖLLATH, R., 2002: Karolingerzeitliche Gräberfelder in Nordostbayern. Eine archäologisch-historische Interpretation mit der Vorlage der Ausgrabungen von K. Schwarz in Weismain und Thurnau-Alladorf. Bd. I: Text, Bd. II: Abbildungen, Listen, Literatur, Bd. III: Katalog, Bd. IV: Tafeln. München. 
PROFANTOVÁ, N., 2015: Nová raně středověká výšinná poloha z Kosoře a Prahy-Radotína. In: V za(u)jetí malostranských stratigrafií: sborník k životnímu jubileu Jarmily Čihákové (Podliska, J., ed.), 80-95. Praha.

- 2016: Ostruhy jako doklady přítomnosti elity v 8. a 9. století v Čechách - Sporen als Belege für die Präsenz von Eliten im 8. und 9. Jahrhundert in Böhmen, AH 41, 7-40.

- 2016a: Tepací formy 7.-8. století z České republiky. In: Od Bachórza do Światowida ze Zbrucza. Tworzenie się słowiańskiej Europy w ujęciu archeologicznym, historycznym i językoznawczym. Księga jubileuszowa Profesora Michała Parczewskiego (Chudzińska, B.-Wojenka, M.-Woloszyn, M., edd.), 57-72. Kraków - Rzesów.

- 2018: Fremd und örtlich. Fernkontakte und die Einbindung fremder Elemente in die lokale Kultur, Beispiel Mittelböhmen. In: Archäologische Arbeitsgemeinschaft Ostbayern/West- und Südböhmen/Oberösterreich, 27. Treffen (Schmotz, K.-Gruber, P.-Chytráček, M., edd.), 235-251. Schlögen.

- v tisku: Poznání hradiště kombinovaným detektorovým, povrchovým průzkumem, geofyzikou a malou sondáží. Příklad Tismice, okr. Kolín (8.-9. století). In: Współczesne metody badań wczesnośredniowiecznych grodów Europy Środkowo-Wschodniej (Moździoch, S., ed.). Wrocław.

PROFANTOVÁ, N.-STOLZ, D., 2006: Kovové nálezy z hradiště v Tismicích a pokus o interpretaci významu hradiště, ASČ 10, 793-838.

PROFANTOVÁ, N. a kol., 2015: Klecany. Raně středověká pohřebiště I. Praha.

REJHOLCOVÁ, M., 1995: Pohrebisko v Čakajovciach (9.-12. storočie). Analýza. Nitra.

RICHTER, M., 1982: Hradišt'ko u Davle. Městečko ostrovského kláštera. Praha.

REMPEL, H., 1966: Reihengräberfriedhöfe des 8. bis 11. Jahrhunderts aus Sachsen-Anhalt, Sachsen und Thüringen. Deutsche Akademie der Wissenschaften zu Berlin. Schriften der Sektion für Vor- u. Frühgeschichte 20. Berlin.

SCHWARZ, K., 1984: Frühmittelalterlicher Landesausbau im ostlichen Franken zwischen Steigerwald, Frankenwald und Oberpfälzer Wald. Mainz.

SLÁMA, J., 1990: Slovanské pohřebiště. In: Lochenice. Z archeologických výzkumů na katastru obce. Praehistorica 16 (Buchvaldek, M.-Zeman, J., red.), 103-134. Praha.

SPIONG, S., 2000: Fibeln und Gewandnadeln des 8. bis 12. Jahrhunderts in Zentraleuropa: eine archäologische Betrachtung ausgewählter Kleidungsbestandteile als Indikatoren menschlicher Identität. Zeitschrift für Archäologie des Mittelalters. Beiheft 12. Bonn.

SZÖKE, B. M., 2010: Mosaburg/Zalavár und Pannonien in der Karolingerzeit, Antaeus 31-32, 9-52.

ŠOLLE, M., 1966: Stará Kouřim a projevy velkomoravské hmotné kultury v Čechách. Praha.

ŠTEFAN, I.-KRUTINA, I., 2009: Raně středověké sídliště, hromadný hrob a pohřebiště na Budči, PA C, $119-212$.

UNGERMAN, Š., 2009: Archaika in den frühmittelalterlichen Gräbern in Mähren. In: My Things Changed Things. Social Development and Cultural Exchange in Prehistory, Antiquity, and the Middle Ages (Mař́ková Vlčková, P.-Mynářová, J.-Tomášek, M., edd.), 224-256. Prague.

VIDA, T., 1997/1998: Veil pin or dress pin. Data to the question of Avar period pin-wearing, Antaeus 24, $563-574,811-815$.

\section{Zusammenfassung}

\section{Eine Eisennadel vom Burgwall Kněží hora bei Katovice (Bezirk Strakonice) und schwer datierbare Nadelfunde aus Höhensiedlungen in breiteren Zusammenhängen}

Die aus verschiedenen Materialien hergestellten frühmittelalterlichen Nadeln gehören im breiteren europäischen Kontext zu den weniger gängigen Funden. Die besonders von Kněží hora bei Katovice und aus Tismice stammenden neu gefundenen Exemplare sind ein Beleg für den Verbreitungsgrad dieses Artefaktes, ferner für eine mögliche Andersartigkeit sich zu kleiden in der Umgebung von mittelalterlichen Höhenlagen und tragen zur Diskussion bezüglich Datierung und Interpretation von solitären Artefakten bei, die außerhalb in sich geschlossener Komplexe gefunden wurden. Im Falle des unvollständigen Exemplars vom Burgwall Kněží hora bei Katovice (Bezirk Strakonice) handelt es sich wahrscheinlich um den ersten Fund einer frühmittelalterlichen Nadel in Südböhmen überhaupt. Die gefundene Nadel mit dem walzenförmig gegliederten Hals weist bis zu einem gewissen Grad nicht nur zu den aus der großmährischen 
und merowingisch-karolingischen Umgebung stammenden Exemplaren eine Ähnlichkeit auf, sondern auch zu Exemplaren, die in die Stufe B2 der Römerzeit datiert werden, und zwar besonders im Hinblick auf den walzenförmig gegliederten Hals der gefundenen Nadel. Hier tendieren wir aber eher zu einem frühmittelalterlichen Alter dieser Nadel. Jedoch schließen wir auch die Möglichkeit nicht aus, dass sie formenmäßig von Nadeln aus der Römerzeit inspiriert wurde. Die Funde von Nadeln (10 Exemplare) aus Buntmetall sind am zahlreichsten in dem vom Ackerbau gestörten Siedlungskontext des ausgedehnten Burgwalls Tismice in Mittelböhmen (8.-9. Jahrhundert) vertreten. Allerdings ist ihre Datierung für gewöhnlich nicht eindeutig, besonders im Hinblick auf die solitären Metallartefakte aus der Römerzeit, die bei der Prospektion dieser Fundstelle neu entdeckt wurden. Der Typ mit kugelförmigem Kopf und der Umfangverzierung kam an der Fundstelle in gleicher Form zweimal vor und hat Analogien zum Gräberfeld an der Kirche Nr. I in Břeclav-Pohansko, in der Hadrianskirche von Zálavár aus wohl der Mitte des 9. Jahrhunderts sowie in den etwas älteren Gräbern im Westen. Die Nadeln aus Tismice sind eher gegossen und die Verzierung ist gröber, es handelt sich wahrscheinlich um eine gängigere und billigere Variante. Einige von den anderen Nadeln zählen eher zum Frühmittelalter und stellen die vereinzelte Spur einer Frauentracht in der Zeit vor Aufkommen der Skelettbestattungen in Böhmen dar. Neue Nadelfunde in Böhmen belegen dann nicht nur die Kompliziertheit der Heranziehung eines aussagekräftigen Potenzials der mittels Metalldetektoren gefundenen Kollektionen, sondern auch das breite Spektrum der Bezüge und Einflüsse aus verschiedenen Gebieten Europas, von denen die frühmittelalterliche Sachkultur geformt wurde. Auch bleibt die Frage weiterhin offen, bis zu welchem Grade die Funde von Burgwällen die bislang nicht adäquat erkannten bzw. sehr kargen Grabkomplexe (Brandbestattungshügeln) in Böhmen für den älteren Abschnitt des Frühmittelalters (ungefähr bis Mitte des 9. Jahrhunderts) ersetzen. Es ist offenkundig, dass diese Untersuchungen von destruktiven Grabungen mit klaren Kontexten ergänzt werden müssen. Ohne diese kombinierte Grabungsstrategie bleibt ein großer Teil der Funde von Oberflächenuntersuchungen chronologisch nicht zugeordnet.

Der Anteil von N. Profantová entstand im Rahmen des vom Förderprojekt GAC̆R Nr. 18-00477S geförderten Projektes „Zwischen dem awarischen und karolingischem Reich“.

PhDr. Josef Hložek, Ph.D., Katedra archeologie Fakulty filozofické Západočeské univerzity v Plzni, Sedláčkova 15, 30100 Plzeň; Archeologický ústav AV ČR, Praha, v. v. i., Letenská 4, 11801 Praha 1, Česká republika,hlozek@kar.zcu.cz,hlozek@arup.cas.cz

PhDr. Petr Menšík, Ph.D., Katedra archeologie Fakulty filozofické Západočeské univerzity v Plzni, Sedláčkova 15, 30100 Plzeň, Česká republika,pmensik@kar.zcu.cz

PhDr. Nad’a Profantová, CSc., Archeologický ústav AV ČR, Praha, v. v. i., Letenská 4, 11801 Praha 1 , Česká republika,profantova@arup.cas.cz 